Araştırma Makalesi / Research Article

Kimya / Chemistry

Iğdır Üniversitesi Fen Bilimleri Enstitüsü Dergisi, 9(3): 1486-1491, 2019

Journal of the Institute of Science and Technology, 9(3): 1486-1491, 2019

\title{
Investigation of Dissolution Kinetics of Tincal Mineral in Ammonium Acetate Solution in High Solid / Liquid Ratios
}

\author{
Mehmet Salih NAS ${ }^{1 *}$, Adnan YILDIZ ${ }^{2}$
}

\begin{abstract}
The chemical formula of tincal mineral used in this study is $\mathrm{Na}_{2} \mathrm{O}-2 \mathrm{~B}_{2} \mathrm{O}_{3}-10 \mathrm{H}_{2} \mathrm{O}$. The tincal ore, one of the important boron minerals, is extracted around Eskişehir in Turkey. Herein, we investigated the kinetics of dissolution in different parameters such as concentration, particle size, solid / liquid ratio, mixing speed and reaction temperature in the ammonium acetate solution of tincal mineral. As a result, boric acid production obtained by dissolution of tincal mineral in amunium acetate solution increased with temperature increase. However, in the dissolution process, boric acid production was found to be reduced by the increase in particle size and solid-liquid ratio.
\end{abstract}

Keywords: Boron minerals, tincal, ammonium acetate, dissolution, boric acid.

\footnotetext{
${ }^{1}$ Mehmet Salih NAS (Orcid ID: 0000-0001-1092-5237), Iğdır Üniversitesi, Mühendislik Fakültesi, Çevre Mühendisliği Bölümü, Iğdır, Türkiye.

${ }^{2}$ Adnan YILDIZ (Orcid ID: 0000-0001-9084-7608), Yüzüncü Y1l Üniversitesi Eğitim Fakültesi, Kimya Bölümü, Van, Türkiye

*Sorumlu Yazar: Mehmet Salih NAS, e-mail: msnas34@gmail.com

Bu çalışma Mehmet Salih NAS'ın Yüksek Lisans tezinin bir bölümüdür.
}

Geliș tarihi / Received:15.03.2019 Kabul tarihi / Accepted:16.04.2019 


\section{INTRODUCTION}

Boron is an invaluable mineral in the industrial field. It is found in nature in the form of borates (oxides). The most important boron minerals are tincal $\left(\mathrm{Na}_{2} \mathrm{~B}_{4} \mathrm{O}_{7} 10 \mathrm{H}_{2} \mathrm{O}\right)$, colemanite $\left(\mathrm{Ca}_{2} \mathrm{~B}_{6} \mathrm{O}_{11} 5 \mathrm{H}_{2} \mathrm{O}\right)$, ulexite $\left(\left(\mathrm{Na}_{2} \mathrm{O}_{2} \mathrm{CaO}_{5} \mathrm{~B}_{2} \mathrm{O}_{3} 16 \mathrm{H}_{2} \mathrm{O}\right)\right.$ and datolite $\left(\mathrm{Ca}_{2} \mathrm{~B}_{2} \mathrm{O}_{5} \mathrm{Si}_{2} \mathrm{O}_{5} \mathrm{H}_{2} \mathrm{O}\right)$. Turkey has a very rich boron beds. Eskisehir- Kirka in Turkey are known to have the world's largest boron reserves. Boron minerals are used as raw materials in many industries (Balasubramanian et al., 2008; Dogan and Yartaş1, 2009; Garret, 1998; Ekmekyapar et al., 2008; Helvac1, 1978; Gönen et al., 2011; Ozmetin et al., 1996; Parks and Edwards, 2005). Boron compounds are a very important mineral used for different purposes such as cosmetics, leather, ceramics, rubber, paint, textile, agriculture and catalyst (Balasubramanian et al., 2008). One of the most important boron compounds is tincal. Tincal mineral, $\mathrm{Na}_{2} \mathrm{~B}_{4} \mathrm{O}_{7} 10 \mathrm{H}_{2} \mathrm{O}$, has a crystal structure and an odorless white color. It is also important for boric acid production by treating tincal mineral with different chemical solvents (King and Mbroo, 1992; Temur et al., 2000). Boric acid present in boron minerals and used extensively in boron industrially to produce some chemicals like boron carbide, boron phosphate, organic boron and esters est (Garret, 1998; King and Mbroo, 1992; Ozmetin et al., 1996). Literature containe various works about the dissolution of boron compounds in aqueous solution medium. The studies related to the dissolution of boron minerals are briefly summarized below. Researchers performed the study in an oxalic acid environment to dissolve the tincal mineral (Abali et al., 2006;2007). In addition, it was observed in the dissolution reaction that it increased with temperature and mixing speed, decreased with solid / liquid ratio and decrease in particle size. The researchers investigated the dehydration and dissolution kinetics of tincal ore of boron compounds from the Kurka region. The effect of both tincal and calcined tincal samples on different parameters in both water and hydrochloric acid solutions was investigated (Gedikbey and Birlik, 2004). The researchers observed that contents of tincal in boron mineral were completely removed from the crystal in the range of $350-400{ }^{\circ} \mathrm{C}$. The dehydration kinetics of both tincal and borax mineral from boron compounds were analysed using DTA and TGA analysing methods (Ekmekyapar et al., 1997). Researchers treated with ammonium carbonate solution to examine the kinetic mechanisms of tincal mineral. They determined that the dissolution rate increased with increasing mineral concentration and reaction temperature and the rate of dissolution was decreased as the particle size and solid-liquid ratio decreased (Y1ldiz et al., 2010). In experiments, it was aimed to investigate the dissolution rate of the tincal ore in ammonium acetate solutions on parameters such as particle size, solution concentration, mixing speed, solidliquid ratio and reaction temperature.

\section{MATERIAL AND METHODS}

The tincal mineral used in the studies was obtained from Eskişehir Kırka Eti Bor facilities belonging to Etibank. The mineral was removed from the mineral bed without being cleaned from the impurities and it was broken by a laboratory size breaker. Ore, A.S.T.M. with standard sieves divided into grain sizes of $-14+30,-30+40,-40$ $+60,-60+140$ mesh. Some properties of the tincal mineral used in the study and the experimentally determined chemical composition are given in Table 1. 
Table 1. The chemical composition of tincal used in experiments

\begin{tabular}{lc}
\hline Constituent & Percentage present $(\%)$ \\
\hline $\mathrm{Na}_{2} \mathrm{O}$ & 14.88 \\
$\mathrm{~B}_{2} \mathrm{O}_{3}$ & 34.06 \\
$\mathrm{H}_{2} \mathrm{O}$ & 41.10 \\
$\mathrm{SiO}_{2}$ & 1.2 \\
$\mathrm{CaO}$ & 4 \\
$\mathrm{Others}$ & 4.76 \\
\hline
\end{tabular}

Dissolution was carried out at $250 \mathrm{ml}$ of a double-walled glass reactor and at atmospheric pressure. A mechanical stirrer is used for mixing and the HAAKE circulator is used at a constant temperature to keep the reaction temperature constant. The parameters and parameter values used in decoding operations are given in Table 2. These parameters were examined between 3-30 minutes.

Table 2. Parameters used in the operation and the value of these parameters

\begin{tabular}{ll}
\hline \multicolumn{1}{c}{ Constituent } & \multicolumn{1}{c}{ Values } \\
\hline Particle size (mesh) & $-14+30,-30+40^{*},-40+60,-60+140$ \\
Solution concentration $\left(\mathrm{mol} . \mathrm{ml}^{-1}\right)$ & $0.01 *, 0.02,0.035,0.050$ \\
Solid / Liquid Ratio $\left(\mathrm{g} \cdot \mathrm{ml}^{-1}\right)$ & $0.04 *, 0.06,0.08,0.1$, \\
Reaction Temperature $(\mathrm{K})$ & $293.15,299.15^{*}, 307.15,315.15$ \\
Mixing Speed (dev. Min. $\left.{ }^{-1}\right)$ & $350,500^{*}, 800,1100$ \\
\hline
\end{tabular}

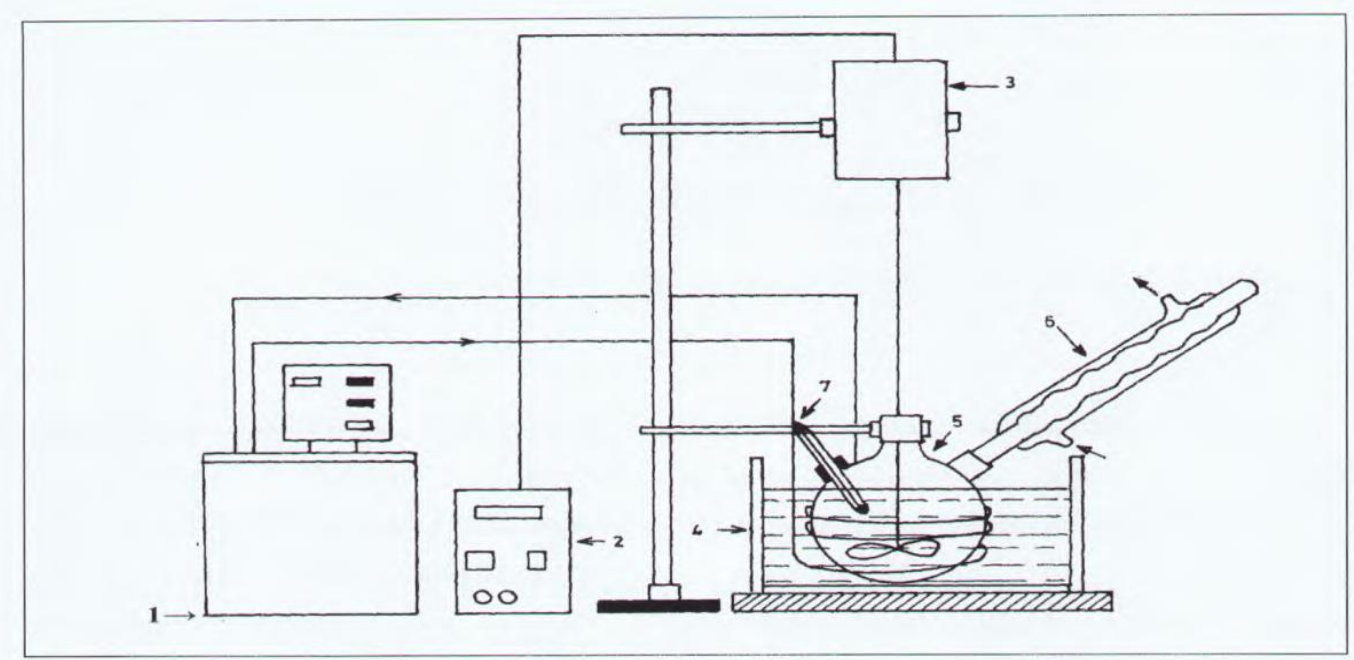

Figure 1. Experimental setup used in working processes. 1.Constant temperature circulator.2.Tachometer (Speed Adjuster), 3. Mechanical mixer, 4.Constant temperature bath, 5. Reactor, 6. Back-cooler, 7. Thermometer.

\section{RESULTS AND DISCUSSION}

Dissolution rate of tincal ore in $\mathrm{NH}_{4} \mathrm{CH}_{3} \mathrm{COO}$ solutions; The effects of grain size, acid concentration, solid-liquid ratio, mixing speed and reaction temperature were investigated.
The possible dissolution process and reactions of the tincal ore when added to the ammonium acetate solution are as follows: 


$$
\begin{aligned}
& \mathrm{Na}_{2} \mathrm{O} .2 \mathrm{~B}_{2} \mathrm{O}_{3} \cdot 10 \mathrm{H}_{2} \mathrm{O}_{(\mathrm{S})} \rightarrow 2 \mathrm{Na}_{(a q)}{ }^{+}+2 \mathrm{H}_{3} \mathrm{BO}_{3}(\mathrm{aq})+2 \mathrm{~B}(\mathrm{OH})_{4(a q)}+3 \mathrm{H}_{2} \mathrm{O}(\mathrm{s}) \\
& \left.\mathrm{B}(\mathrm{OH})_{4(a q)}\right)^{-}+\mathrm{H}_{3} \mathrm{O}_{(a q)}{ }^{+} \leftrightarrow \mathrm{H}_{3} \mathrm{BO} 3(a q)+2 \mathrm{H}_{2} \mathrm{O}(\mathrm{s})
\end{aligned}
$$

The total reaction is;

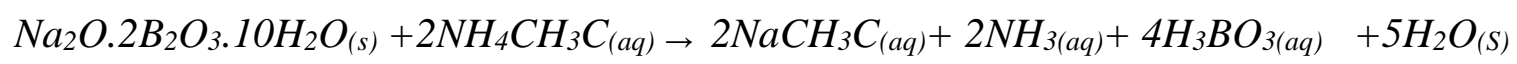

\section{Effect on particle size resolution}

To examine the composition of the grain size, fractions of $-14+30,-30+40,-40+60,-60$ +140 mesh were taken. In the experiments, the reaction temperature was $293.15 \mathrm{~K}$, the acid concentration was $0.01 \mathrm{M}$, the solid-liquid ratio was $4 \mathrm{~g} / 100 \mathrm{ml}$, the mixing rate was fixed at 500 rpm. The effect of grain size on the transformation speed was investigated and the results are shown in Figure 2. As can be seen, as the particle size decreases, the rate of conversion of tincalin boric acid is increased in unit time.

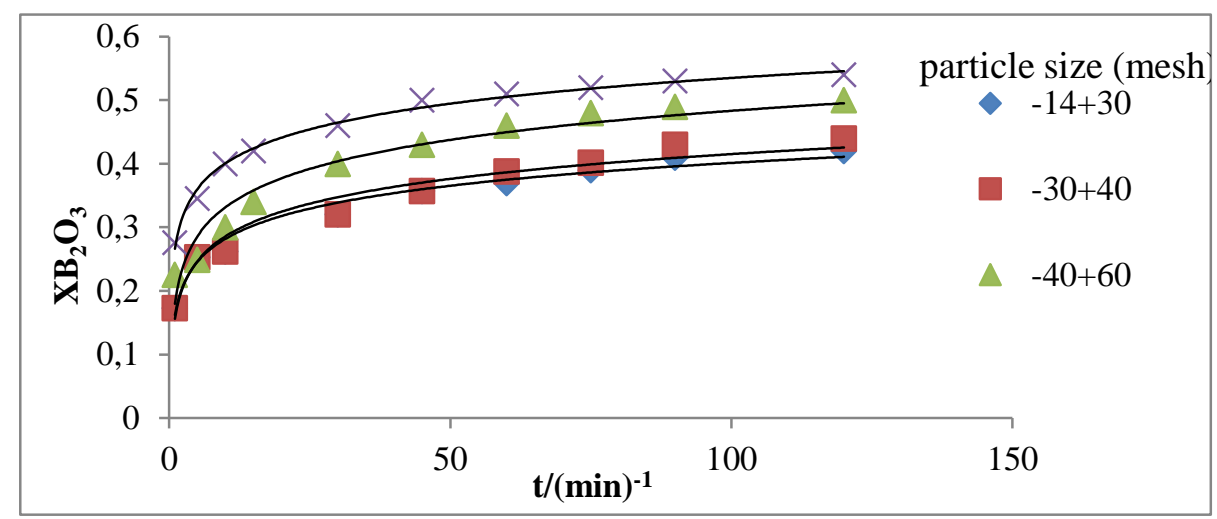

Figure 2. Effect on particle size resolution on the rate of conversion of tincal ore to boric acid

\section{The effect of solution concentration on the rate of conversion of tincal ore to boric acid}

The effect of acid concentration was investigated using the first acid concentrations of $0.01,0.02,0.035$ and 0.05 moles, respectively. In the experiments, the reaction temperature was 299.15 K, the solid-liquid ratio was $4 \mathrm{~g} / 100 \mathrm{ml}$, the mixing speed was $500 \mathrm{rpm}$ and the ore size was kept as $(-30+40)$ mesh. The results are plotted in Figure 3. As can be seen, increasing the acid concentration increased the dissolution rate.

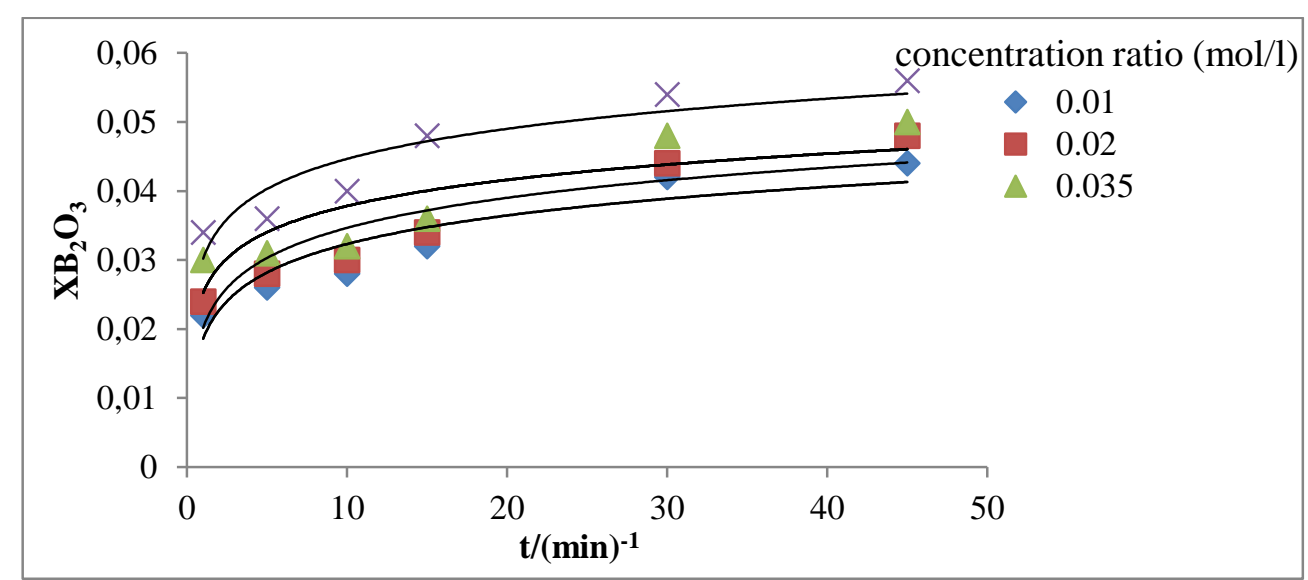

Figure 3. The effect of solution concentration on the rate of conversion of tincal ore to boric acid 


\section{Effect of solid-liquid ratio and temperature on Solubility}

The effect of the solid-liquid ratio was examined using solid-liquid ratios of 0.04, 0.06, 0.08 and $0.1 \mathrm{~g}$. The results are plotted in Figure 4. As can be seen, the rate of dissolution decreased by increasing the solid-liquid ratio. The effect of the reaction temperature was examined using reaction temperatures of $20,26,34$ and $42{ }^{\circ} \mathrm{C}$. In the experiments, the solution concentration was $0.01 \mathrm{M}$, the ore size was $-30+40$ mesh, the solidliquid ratio was $4 \mathrm{~g} / 100 \mathrm{ml}$ and the mixing speed was kept constant at $500 \mathrm{rpm}$. The test results are shown in Figure 5. As a result, the dissolution rate at $42{ }^{\circ} \mathrm{C}$ was highest.

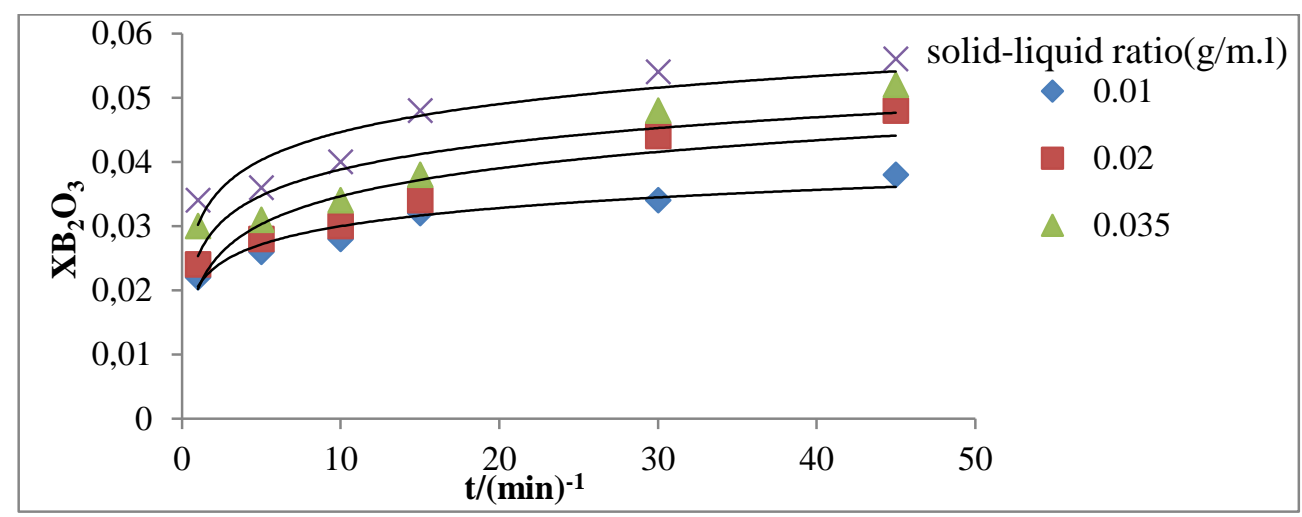

Figure 4. Effect of solid-liquid ratio and on Solubility

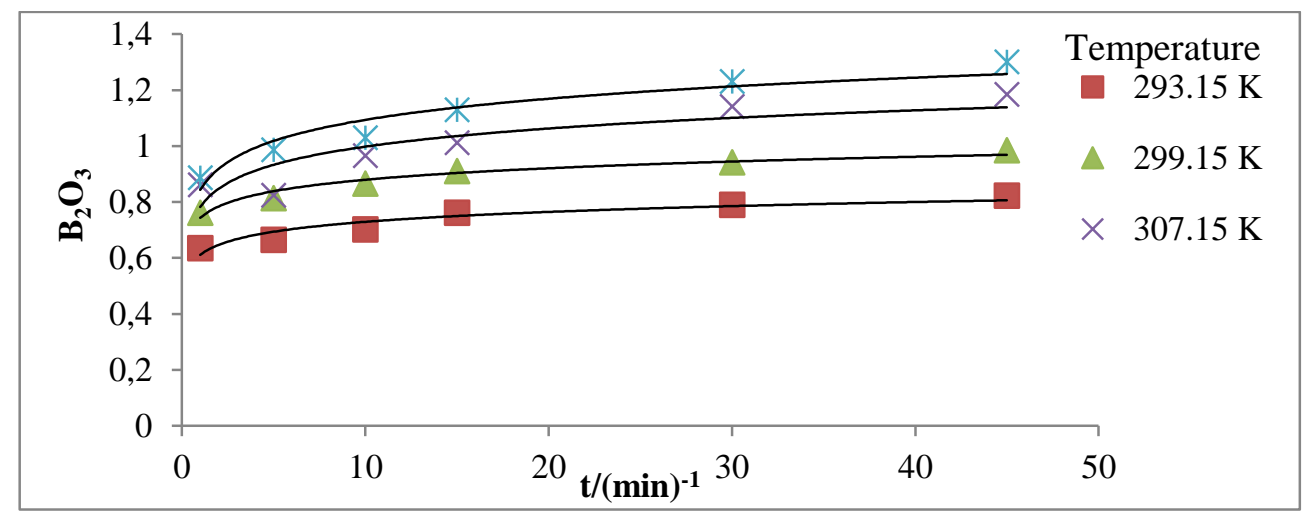

Figure 5. The effect on the reaction temperature of conversion of tincal ore to boric acid

\section{CONCLUSION}

In experiments, it was aimed to investigate the dissolution rate of the tincal ore in ammonium acetate solutions on parameters such as particle size, solution concentration, mixing speed, solidliquid ratio and reaction temperature. In order to examine the effect of grain size on the transformation rate, fractions of $-14+30,-30+$ $40,-40+60,-60+140$ mesh were used. In the trials, the reaction temperature was $299.15 \mathrm{~K}$, the solution concentration was $0.01 \mathrm{M}$, the solidliquid ratio was $4 \mathrm{~g} / 100 \mathrm{ml}$, the mixing speed was 500 rpm. As shown in Fig. 5, the dissolution rate increases as the grain size decreases. By decreasing the particle size, the number of particles per unit weight and thus the surface area increases. As the contact surface between the fluid reactant and the solid particle will increase, the conversion fraction is expected to increase. The effect of the solution concentration on the 
dissolution rate increased with increasing acid concentration and the rate of dissolution. As shown by the transfer to figure 3 , the rate of conversion decreases with the increase of the solid / liquid ratio. As the amount of solids in the environment increased, the rate of conversion was also reduced due to the decrease in the amount of liquid converted into solids. It was determined that the mixing speed in the studied range did not have any significant effect on the conversion fraction of tincaline. During the dissolution of the tincal, a mixing speed (500 rpm) in which the full suspension can be achieved appears to be sufficient. As can be seen in figure 5, with the increase in temperature, the amount of tincalin which is converted into boric acid in unit time increases rapidly due to the increase in the average kinetic energies of the molecules and the number of unit collisions per unit time.

\section{REFERENCES}

Abalı Y, Bayca S.U, Mistincik E, 2006. Kinetics of Oxalic Acid Leaching of Tincal, Chem. Eng. J., 123, 25-30.

Abalı Y, Bayca S.U, Guler A.E, 2007. The Dissolution Kinetics of Tincal in Phosphoric Acid Solutions, Int. J. Chem. React. Eng., 5(1).

Balasubramanian R, Lakshmi Narasimhan T.S, Viswanathan R, Nalini S, 2008. Investigation of the vaporization of boric acid by transpiration thermogravimetry and Knudsen effusion mass spectrometry, J. Phys. Chem., B 112, 13873-13884.

Dogan H.T, Yartaş1 A, 2009. Kinetic investigation of reaction between ulexite ore and phosphoric acid, Hydrometallurgy., 96, 294-299.

Ekmekyapar A, Demirkıran N, Künkül A, 2008. Dissolution kinetics of ulexite in acetic acid solutions, Chem. Eng. Res. Design., 86, 10111016.

Ekmekyapar A, Baysar A, Kunkul A, 1997. Dehydration Kinetics of Tincal and Borax by Thermal Analysis, Ind. Eng. Chem. Res., 36, 3487-3490.
Garret D.E, 1998. Borates, Academic Press, New York.

Gedikbey T, Birlik E, 2004. Kırka Tinkalinin Dehidratasyonunun ve Çözünürlüğünün Belirlenmesi, Paper Presented at The 2nd International Boron Symposium, September 23-25, in Eskişehir, Turkiye.

Gönen M, Balköse D, Ülkü S, 2011. Supercritical ethanol drying of zinc borates of $2 \mathrm{ZnO} \cdot 3 \mathrm{~B} 2 \mathrm{O} 3 \cdot 3 \mathrm{H} 2 \mathrm{O}$ and $\mathrm{ZnO} \cdot \mathrm{B} 2 \mathrm{O} 3 \cdot 2 \mathrm{H} 2 \mathrm{O}$, J. Supercrit. Fluids., 59, 43-52.

Helvac1 C, 1978. A Review of The Mineralogy of The Turkish Borate Deposits, Mercian Geol., 6, 257-270.

King R.B, Mbroo R. B, 1992. Encylopedia of Inorganic Chemistry, vol 1, John Wiley \& Sons, New York.

Özdemir M, 'Kıpçak İ, 2010. Recovery of boron from borax sludge of boron industry, Miner. Eng., 23, 685-690.

Ozmetin C, Kocakerim M, Yapıc1 S and Yartası A, 1996. A Semiempirical Kinetic Model for Dissolution of Colemanite in Aqueous $\mathrm{CH}_{3} \mathrm{COOH}$ Solutions, Ind. Eng. Chem. Res., 35, 2355-2359.

Parks J.L, Edwards M, 2005. Boron in the Environment, Crit. Rev. Environ. Sci. Technol., $35,81-114$

Temur H, Yartas1 A, Copur M and Kocakerim M, 2000. The Kinetics of Dissolution of Colemanite in $\mathrm{H}_{3} \mathrm{PO}_{4}$ Solutions, Ind. Eng. Chem. Res., 39, 4114-4119.

Yıldız A, Nas M. S, Kubilay S, Yılmaz S, 2010. Dissolution and Mechanism of Tincal in Ammonium Carbonate Solutions, Asian J. Chem., 22, 765-771. 